\title{
人エリーフ周辺の流れ・漂砂についての検討 EXAMINATION OF NEARSHORE CURRENTS AND LITTORAL DRIFT AROUND ARTIFICIAL REEF
}

\author{
熟見 浩一1・和田 明 2 \\ Hirokazu SUMI and Akira WADA \\ 1学生員 工修 日本大学大学院 生産工学研究科 (广275 千葉県習志野市泉町1-2-1) \\ 2 正会員 工博 日本大学大学院教授 生産工学研究科 ( 275 千葉県習志野市泉町1-2-1)
}

\begin{abstract}
When installing an artificial reef on the shore, the general practice is to provide an opening width between breakwater bodies. The condition of the nearshore current and littoral drift varies depending on the setting of breakwater length and opening width. In this research, the nearshore current, littoral drift and wave height distribution at the time when the breakwater length and opening width were changed is discussed on the basis of experimental results. The wave height distribution was analyzed numerically. The results of calculations by the time-dependent mild slope equation agree with experimental results. The nearshore current is dependent upon the breakwater length and opening width, and the larger the opening width is reference to the breakwater length the more easily the circulating current is general. The topographic change is affected by flow patterns and deposition occurs on the front shore when circulating current is generated. It was also confirmed that the artificial reef is effective in controlling the littoral drift.
\end{abstract}

Key Words : artificial reef, nearshore current, littoral drift, wave height distribution

\section{1.はじめに}

海岸の環境保全と景観確保，海洋レクリエーショ ン空間の創出等の要請から, 天端面が水面下にある 人エリーフの施工計画例が近年增加している.

人エリーフの設置目的としては大別すると海底を 浅くして砕波を促進し，入射波を減衰させる波浪の 静榣化を実現するものと, 漂砂活動を規制し, 堤体 背後域の砂の流出を防止して一定量の海浜を確保す る海浜の安定化を実現することの 2 通りが挙げられ る. 後者の目的を達成するために, 海岸に複数の人 エリーフを設置する際, 堤体間に開口部を設けて設 置することが一般的である．このとき，人エリーフ の堤長と開口部の長さを変化させることで, 堤体上 と開口部を透過した伝達波の波高変化から特徽的な 海浜流が生じ, それに伴い海岸地形が変化すること

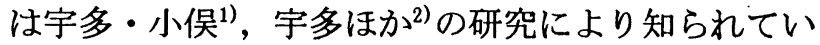
る. しかし, 堤長と開口幅を変化させたときの流況 パターンと海浜変化の関係等の水理特性の定性的な 説明は十分とは言い難い.

そこで本研究では, 複数の人エリーフを設置した 場合, その堤長と開口幅が流れのパターンや循環流 の形成, 海浜の安定化にどのような影響を与えるか 基本的知見を得るため移動床実験を行った. 合わせ て, 人エリーフ周辺の平面波浪場を数值シミュレー
ションを行い推定した.さらに, 実験結果と計算結 果から人エリーフの平面諸元の最適な配置を検討し た.

\section{2. 实験装置と実験方法}

実験には, 平面造波水槽 (長さ $13.0 \mathrm{~m}$, 奥行き $7.6 \mathrm{~m}$, 高さ0.5m)を用いた(図-1)。相似則としてはフルー ドの相似則を採用し，歪みなしとした。縮尺は $1 / 50$ とし, 海浜模型は中央粒径 $\mathrm{dm}=0.19 \mathrm{~mm}$ のケイ砂を用 い初期勾配 $i=1 / 15$ の斜面上に重量が $3 \sim 4 \mathrm{~g}$ の砕石を 基礎マウンドとした人エリーフ模型を設置した。堤 体の断面諸元は法面勾配 $S=1 / 3$, 天端幅 $B=1.0 \mathrm{~m}$, 堤 体高さ $\mathrm{d}=14.0 \mathrm{~cm}$, 天端水深 $\mathrm{R}=6.0 \mathrm{~cm}$ とした. 平面諸 元は図-2に示すように，堤長 $\operatorname{lr}$ と開口幅杖らびに 離岸距離Yからなっている．実験の組み合わせは, 表-1に示すようにした。

作用波浪は，入射波高 $\mathrm{H}_{\mathrm{I}}=6.0 \mathrm{~cm}$, 周期 $\mathrm{T}=1.13 \mathrm{~s}$, 波向きは $0^{\circ}$ (汀線直角方向) として5時間作用させた. 測定項目は海浜流の流況, 海浜地形, 波高分布であ る. 海浜流の流況は図-1に示すように, 沖側から法 尻まで $30 \mathrm{~cm}$ 間隔, 堤体背後では $15 \mathrm{~cm}$ 間隔の正方格子 において人エリーフ周辺の約 350 点となる測定点で, 電磁流速計を用いて静水面下約 $2 \mathrm{~cm}$ の表層の流速を 
表-1 実験ケース

\begin{tabular}{|c|c|c|c|}
\hline ケースNo. & $\operatorname{Lr}(\mathrm{m})$ & W (m) & $\mathrm{Y}(\mathrm{m})$ \\
\hline 1 & 2.0 & 0.3 & 1.8 \\
\hline 2 & 2.0 & 0.75 & 1.8 \\
\hline 3 & 1.0 & 0.22 & 1.8 \\
\hline 4 & 1.0 & 0.75 & 1.8 \\
\hline 5 & 1.0 & 1.25 & 1.8 \\
\hline
\end{tabular}

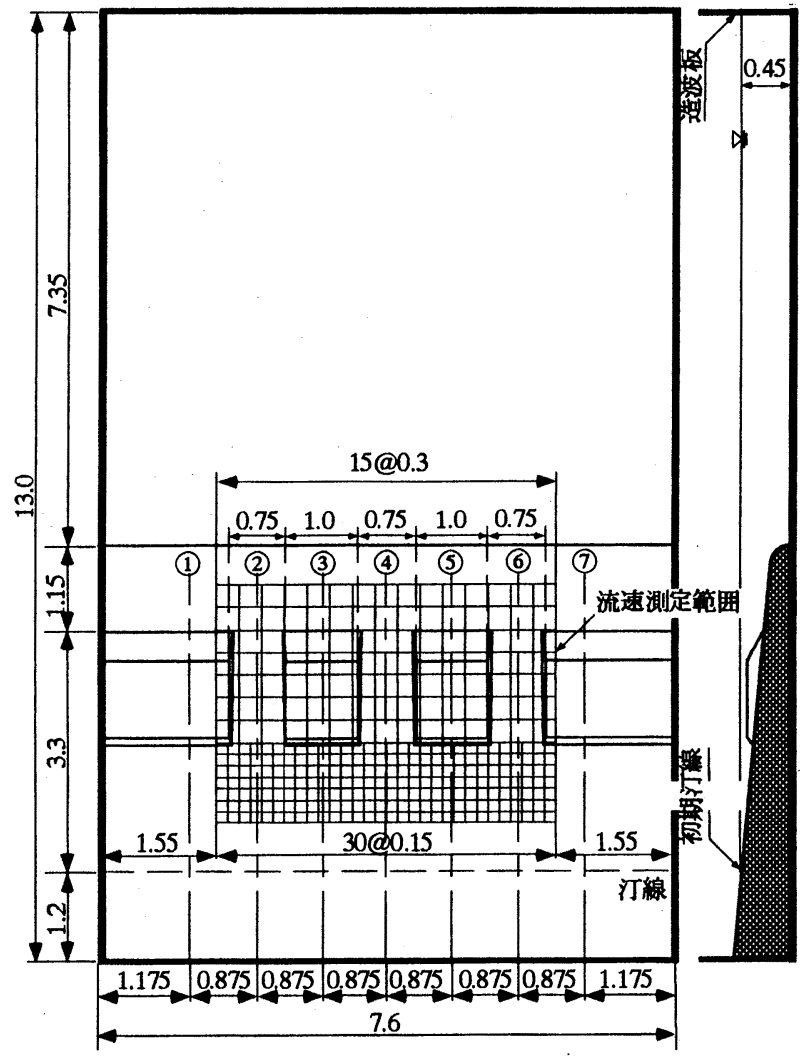

図-1 実験水槽 (単位;m)

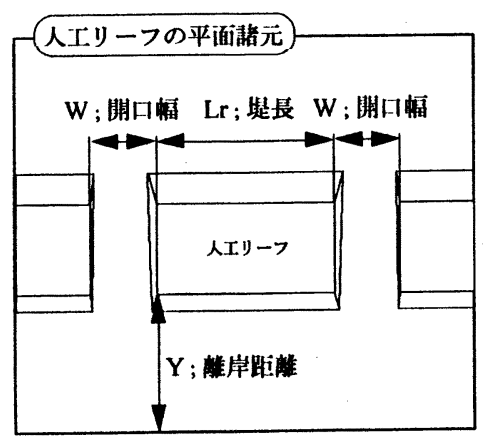

図-2 人エリーフの平面諸元

測定した。海浜地形・波高分布については各実験平 面の組合わせに対し, 汀線直角方向に測線を設け岸 沖方向に $10 \mathrm{~cm}$ 間隔で行った. 流況・波高分布の計測 は，それぞれ造波開始の約 3.5 , 時間後から行った。

\section{3. 波浪計算モデル}

\section{（1）基礎方程式}

人エリーフなどの没水型の海岸構造物を含む波浪 場は，波の屈折，反射および砕波変形を含み，これ らの変形過程をすべて考慮した計算方法を用いる必 要がある. そこで，本研究では、浅海域でのこれら の各変形現象を包括的に評価することが可能である 渡辺・丸山 ${ }^{33}$, 丸山・鹿島 ${ }^{4)}$ による非定常緩勾配方程 式を用いて数值シミュレーションを行うことにした.

静水面を原点とした右手系直行座標における砕波 减衰項を付加した非定常緩勾配方程式は式(1)で与 えられる。

$$
\begin{gathered}
\frac{\partial \vec{Q}}{\partial t}+C^{2} \nabla \zeta+f_{D} \vec{Q}=0 \\
\frac{\partial \zeta}{\partial t}+\frac{1}{n} \nabla(n \vec{Q})=0
\end{gathered}
$$

ここに, $\zeta$ は水面変動, $\vec{Q}=\left(Q_{x}, Q_{y}\right)$ は線流量べク トルである. $C$ を波速, $n$ を浅水度, 波数を $k, \cdot$ 水 深を $h$ としたとき, 角周波数 $\sigma$ は次式で表される.

$$
\left.\begin{array}{l}
\sigma^{2}=g k \tanh k h, C=\sigma / k \\
n=(1 / 2)(1+2 k h / \sinh 2 k h)
\end{array}\right\}
$$

式(1a)の左辺第三項の砕波減衰係数 $f_{D}$ は次式で与 えられる。

$$
\left.\begin{array}{l}
f_{D}=\alpha_{D} \tan \beta \sqrt{\frac{g}{h}\left(\frac{\hat{Q}}{Q_{r}}-1\right)} \\
\hat{Q}=\sqrt{\hat{Q}_{x}^{2}+\hat{Q}_{y}^{2}} \quad, \quad Q_{r}=\gamma^{\prime} \sqrt{g h^{3}}
\end{array}\right\}
$$

ここに、 $\hat{Q}_{x}, \hat{Q}_{y}$ は線流量の振幅, $\tan \beta$ は砕波点 付近の海底勾配, $\alpha_{D}, \gamma^{\prime}$ は定数でそれぞれ 2.5 , 0.25 に相当する.

\section{（2）砕波位置の決定}

砕波位置の決定には, 渡辺ら ${ }^{5)}$ による波の重合場 に対しても適用できるように整理された流速波速比 を用いた。これは, 微少振幅波理論と組み合わせた 場合に，合田 ${ }^{6)} に よ る$ 砕波指標と同じ砕波水深を与 えるように決められたものであり，この砕波指標を 磯部7ににより近似式で示したのが次式である.

$$
\begin{aligned}
(\hat{u} / C)_{b} & =0.53-0.3 \exp \left\{-3 \sqrt{h_{b} / L_{0}}\right\} \\
& +5 \tan ^{3 / 2} \beta \exp \left\{-45\left(\sqrt{h_{b} / L_{0}}-0.1\right)^{2}\right\}
\end{aligned}
$$

ここに, $\hat{u}$ は静水位おける水平流速振幅を表し, 添 字 $b$ は砕波点における值を示す．実際の数值計算で は砕波減衰項を含まない基礎式を用いて $\hat{u} / C$ を計算 領域全体について算定し，この值が式(4)で示され る砕波指標を越えた沖側端を砕波位置とした。

\section{（3）境界条件と計算手順}

実験水槽あるいは港湾などの海洋の一部を想定し て数值計算を行う場合, 計算領域周辺の境界条件と して谷本・小舟 ${ }^{8}$ による任意反射率境界を適用する 
ことができる．任意反射率境界は特性曲線法を用い た手法であり，時刻 $t$ における境界上の点 $\left(x_{0}, y_{0}\right)$ で の線流量を式(5)〜 (7)で与えている.

$$
\begin{gathered}
Q_{x}^{t}\left(x_{0}, y_{0}\right)=A \cdot Q_{x}^{t-\tau}\left(x_{0}-\Delta x, y_{0}\right) \\
A=\frac{1-K_{R}}{\left\{1+K_{R}^{2}-2 K_{R} \cos \left(2 k \Delta x \cos \alpha_{n}\right)\right\}^{1 / 2}} \\
\tan \sigma \tau=\frac{1-K_{R}}{1+K_{R}} \tan \left(k \Delta x \cos \alpha_{n}\right)
\end{gathered}
$$

ここに， $K_{R}$ は反射率， $\alpha_{n}$ は波が境界法線となす角 である．境界上の線流量は $\Delta x$ だけ内側の線流量に 反射率によって決定する無次元係数 $A$ を乗じたもの として求めることができる．また，沖側境界では計 算領域内部からの反射波を外海に透過させるために 式(5)を応用して計算を行う.

数値計算においては, 空間差分間隔を $\Delta x, \Delta y$ と して, 線流量と水位変動の計算点を半格子ずらした スタッガードメッシュを用い，計算時間ステップは 時間間隔を $\Delta t / 2$ 時間ずらして線流量と水位変動を 交互に計算するleap-frog法を採用し，基礎式を離 散化して行う。 $\Delta t$ はCFL条件を満たす值として 0.01 sとした.

\section{4. 人エリーフの水理特性}

\section{（1）人エリーフ周辺の表層の流れ}

図-3は水理実験の結果を示すもので，ケース $1,3,4$ における人エリーフ周辺での表層の流速分布 を示している．流速べクトルはフロートを用いて流 れが定常状態に達したことを確認した上で流速を測 定し，10波を対象として一周期あたりの平均を求め た.

図-3 (a) は比較的開口幅の狭いケース1の流速分布 を示している．堤体上では入射波砕波後の岸向きの 流れが生じ，堤体両端の開口部では沖向きの流れが 発生している. 堤体背後域では弱い岸沖方向の流れ が生じた. 図-3(b) は開口幅の狭いケース3の流速分 布を示している，堤体上では沖向きの流れが発生し， 背後域では向岸流と離岸流が不規則に生じ，不安定 な循環流を形成している. 図-3(c) 汇開口幅の比較 的広いケース 4 の流速分布を示している. 堤体上で は入射波砕波後の岸向きの流れが生じ，背後域では 岸向きの流れが発達し、開口部へと向かう1つの循 環流を形成し，開口部では沖向きの流れとなってい る。

本実験では底層の流れについて検討を行っていな いが，表層付近の流れに着目すると，堤体沖側と開 口部では堤長と開口幅に影響されることなく流況は 沖向きとなるが，堤体より岸側では堤長と開口幅の 設定により, 表層流の流況パターンが異なってく

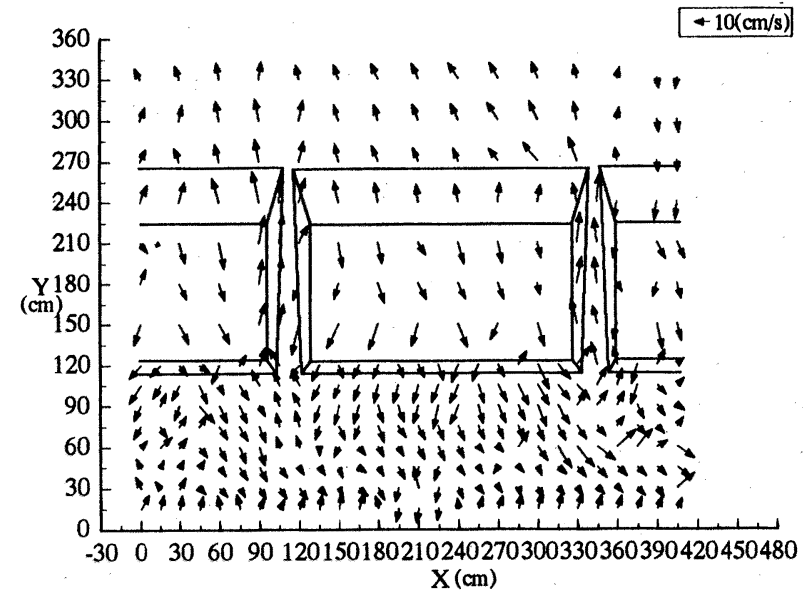

図-3（a） 人エリーフの表層の流速分布（ケース1）

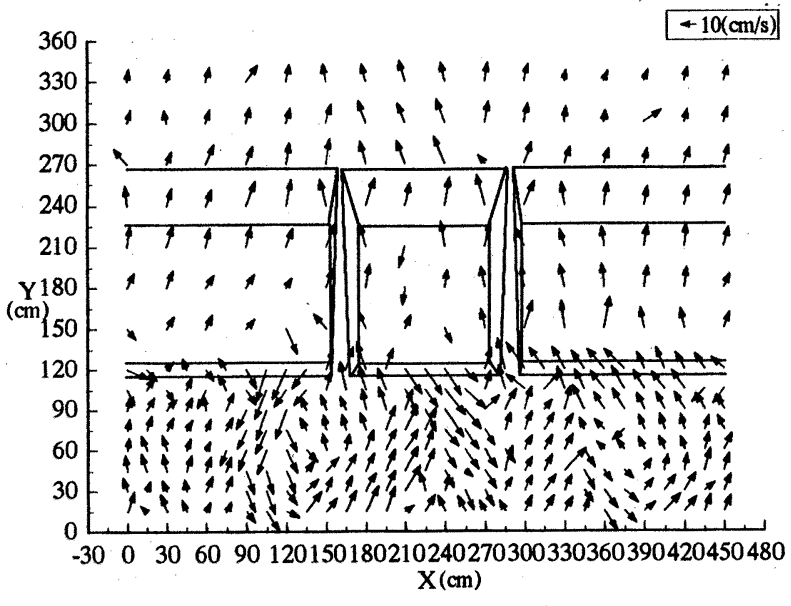

図-3(b) 人エリーフの表層の流速分布(ケース3)

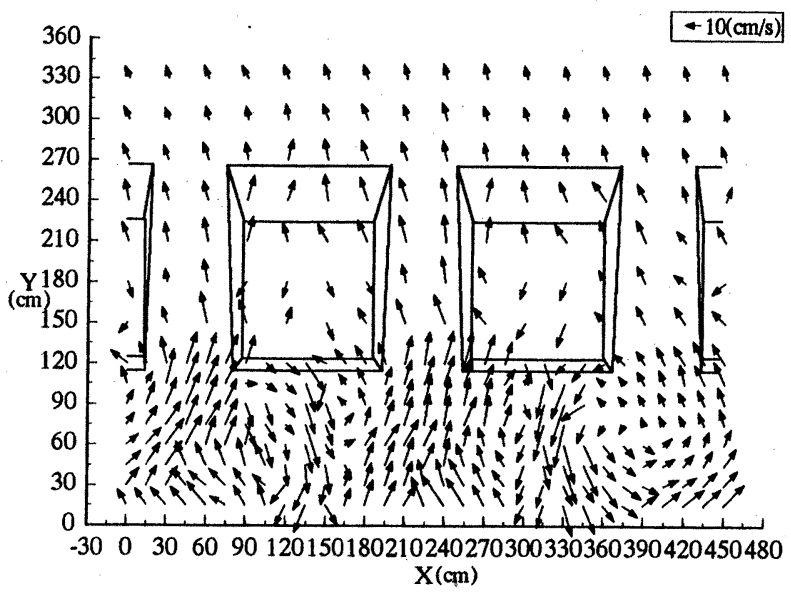

図-3（c）人エリーフの表層の流速分布（ケース4)

ることがわかる，そこで，宇多・小俣1)が示した図4に今回の実験結果をプロットした.

图-4け堤長を開口幅で無次元化した Lr/W之堤長を 離岸距離で無次元化した $\mathrm{Lr} / \mathrm{Y}$ との関係を流況パター ンについて示したものであり, 既往の研究結果と比 較してある. 図中の白で示してある記号は宇多・小 俣 ${ }^{1)}$ 実験結果であり, 黒で示してある記号は本研 究の実験結果である. 堤長Lrに対して開口幅Wが小 


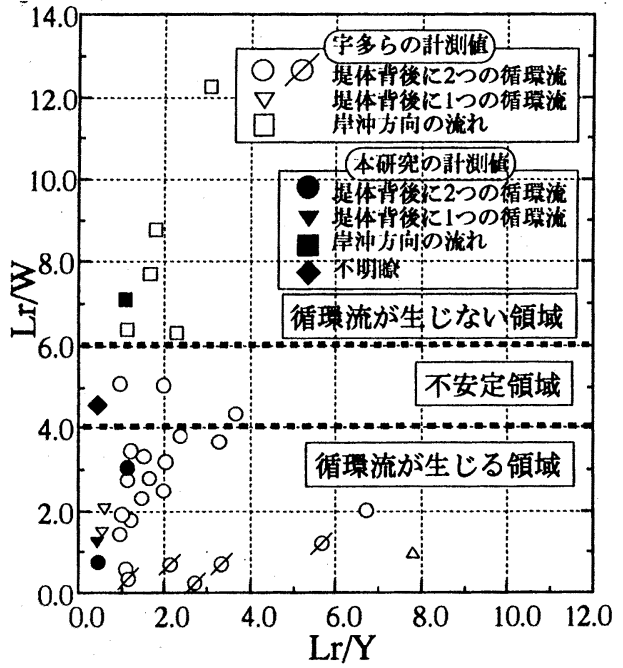

図-4 流況パターン発生区分

さくなり，連続堤のような形態に類似してくると， 岸沖方向の流れが発達し循環流が発生しない傾向に なる，1個あるいは，2個の循環流が発生するケース と, 岸沖方向の流れが卓越するケースは宇多らとほ ぼ同様の結果を示している.

また，本研究で不明瞭な流況パターンを示した ケース3(•)のLr/Wの值が，1個あるいは，2個の循 環流を発生するケース $(\boldsymbol{O}, \boldsymbol{\nabla})$ と岸沖方向の流れが 発生するケース $(\boldsymbol{\square})$ の中間值付近であることを考慮 すると，人エリーフ周辺での表層の流れはLrとWに 支配されていると考えられる.

そこで, 本研究の実験結果と宇多らの研究結果か ら，波が汀線に直角に入射したときの堤体背後域で

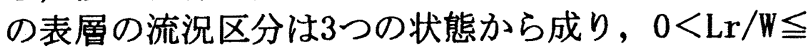
4 では安定した循環流が発生する領域, $4<\mathrm{Lr} / \mathrm{W} \leqq 6$ では不安定な循環流が発生する領域， $6<\mathrm{Lr} /$ Wでは 循環流が発生しない領域とすることができる.

\section{（2）波高分布}

図-5は堤体背後に1つの循環流が発生するケース 4 の平面波浪場の計算結果を示している，計算領域は $9.0 \mathrm{~m} \times 5.8 \mathrm{~m} \times 45 \mathrm{~cm}$ の実験水槽を想定し, 人エリーフ は移動床実験と同じ設計諸元を持つ堤体を地形デー タとして与えた. 作用波浪条件も実験と同様にして ある。

計算結果を見ると沖側から伝播した入射波は天端 上で屈折変形を起こし，汀線に近づくにつれて減衰 していることがわかる．堤体前面には反射波が形成 されていることが確認でき，Y=700 cm付近から沖側 では重複波が形成され，一定の波高值となっている. また，コンター線に短線が直交する箇所は波高の寉 みを示している.

図-6は入射波砕波後の開口部とリーフ上の波高分 布を岸沖方向に示している.この図から波の変形過 程を見ると，入射波が天端上で砕波した後乱れ，再 び砕波点を迎え減衰していることがわかる。このよ うな現象は, 人エリーフの形状と作用波浪条件が密

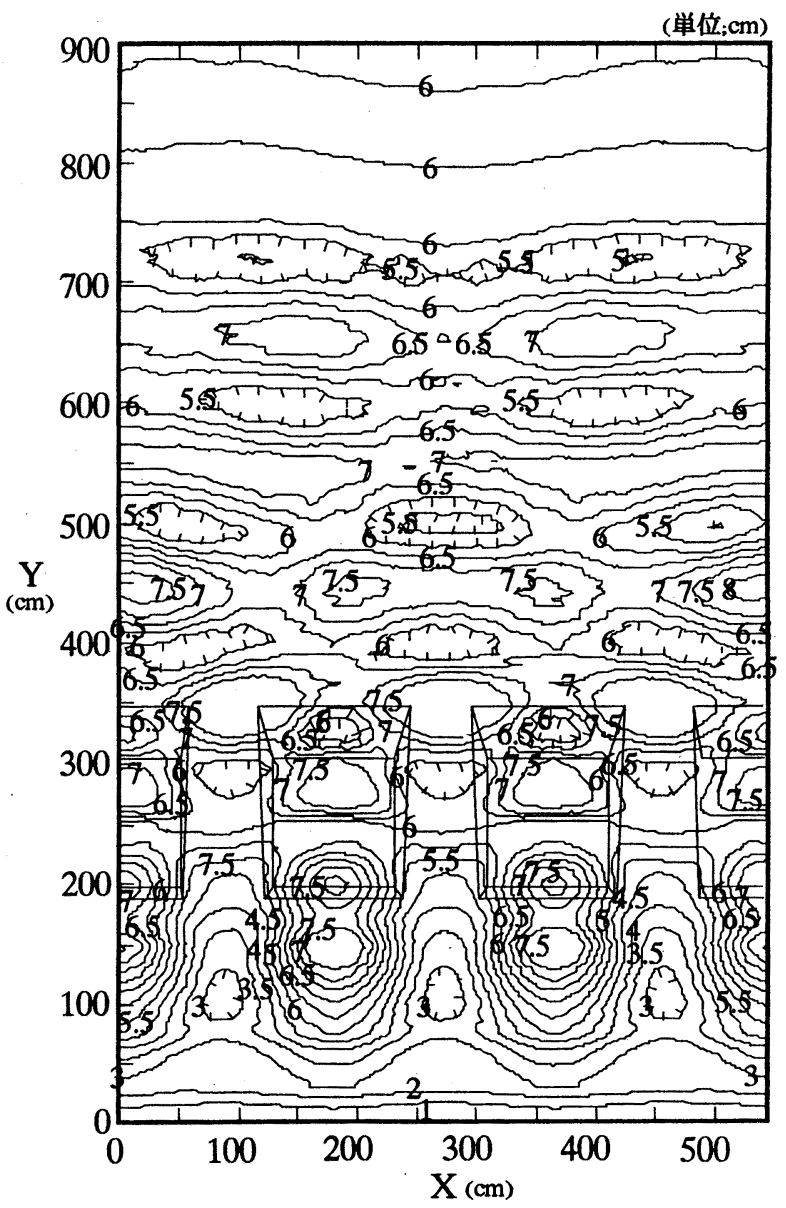

図-5 平面波浪場の計算結果(ケース4)

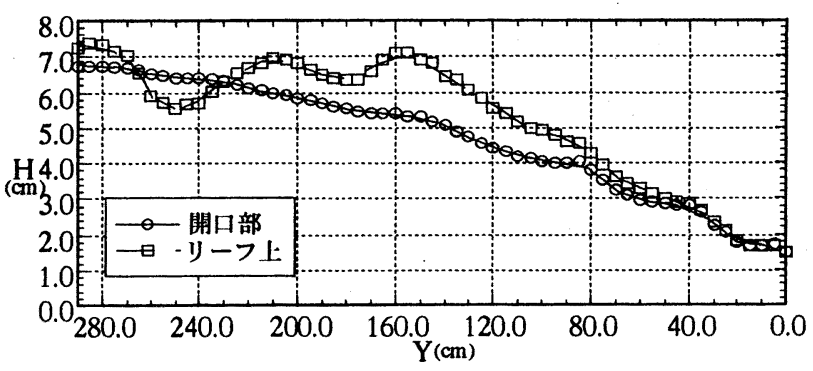

図-6 岸沖方向の波高分布 (ケース4)

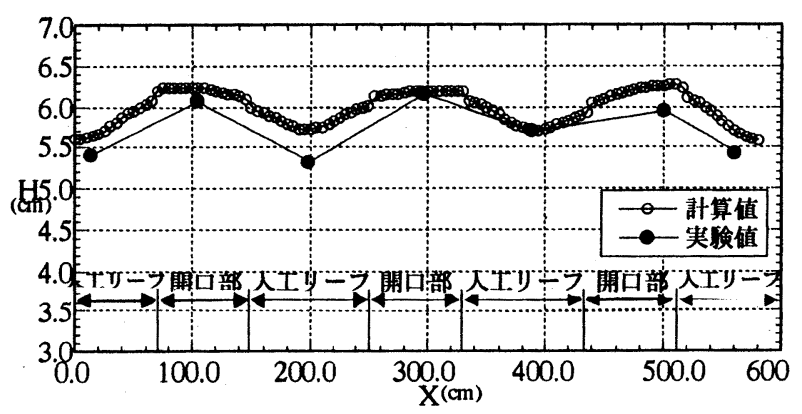

図-7 沿岸方向の波高分布(ケース4)

接に関係し, 天端水深が浅く, 波高が大きいほど起 こりやすい. 数值計算上は式(3)の $Q_{r}$ が波の再生す る限界を示す線流量となっている.

図-7は，図-5, 図-6中のY=250cm付近での波高分布 を沿岸方向に示したものであり, 実験值と比較して 


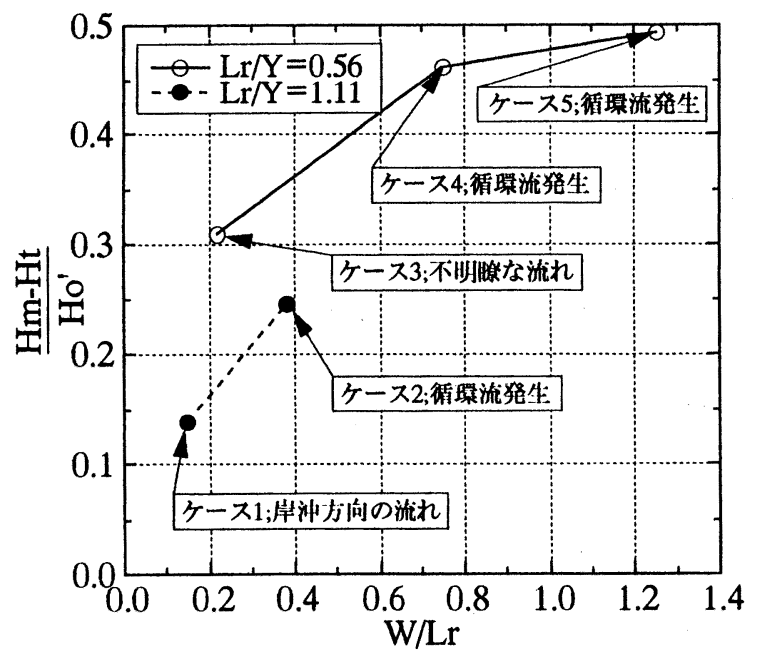

図-8 堤長と開口幅による透過波高の変化

ある．図から開口部では堤体上よりも大きい波高値 を示していることがわかる. また, 計算值と実験值 はほぼ一致している.このように，リーフ上と開口 部での波高の差が循環流の発生に関係しているとし て, 図-8では宇多・小俣 ${ }^{1}$ が採用した座標系を用い て，波高差と平面諸元の関係を示した。

図-8は人エリーフ開口部での波高Hm と堤体背後域 の透過波高Ht との差を換算沖波波高で無次元化した 無次元波高差 $(\mathrm{Hm}-\mathrm{Ht}) / \mathrm{Ho}^{\prime}$ とW/Lrの関係を堤長Lrを 離岸距離Yで除したLr/Yについて示したものである. W/Lrが大きくLr/Yが小さいほど堤体上と開口部での 波高差が大きくなることがわかる，また，W/Lrが大 きくなるほど循環流が発生しやすくなることが，図 -3の流速分布図と合わせて検討するとわかる.

\section{（3）地形変化}

人エリーフ周辺域の漂砂現象には，海浜流が関係 していると考えられる．そこで，海浜流によって引 き起こされる砂の移動を把握するために，造波開始 5 時間後の海浜地形より初期勾配からの海浜地形変 化量の平面的な分布を求めて, 図-9に示した. しか し, 周知のように漂砂に関する実験では相似則が十 分に確立されていないので, 本研究では流体運動に 重点を置きフルードの相似則に従った。この場合， 地形変化に関しては相似則が完全には成立しないが, 流れによる構造物周辺の地形変化を定性的に検討す る上では，有益な資料と思われる。

図-9(a) は，岸沖方向の流れが発生する開口幅の 比較的狭いケース1の地形変化量を示している，堤 体背後で発生した向岸流と離岸流により, 人エリー

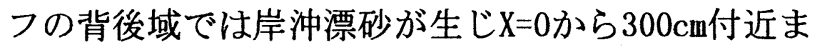
で汀線近傍からY=100 $\mathrm{cm}$ 付近の砂が沿岸方向に侵食 されている. 図-9(b) は, 人エリーフ背後域で2つの 循環流が発生するケース2の地形変化量を示してい る. リーフ上での向岸流が背後域で開口部へと向か う循環流となっていることを考慮して, 砂の収支を 考えてみると, 開口部付近の堆砂は汀線付近の砂が

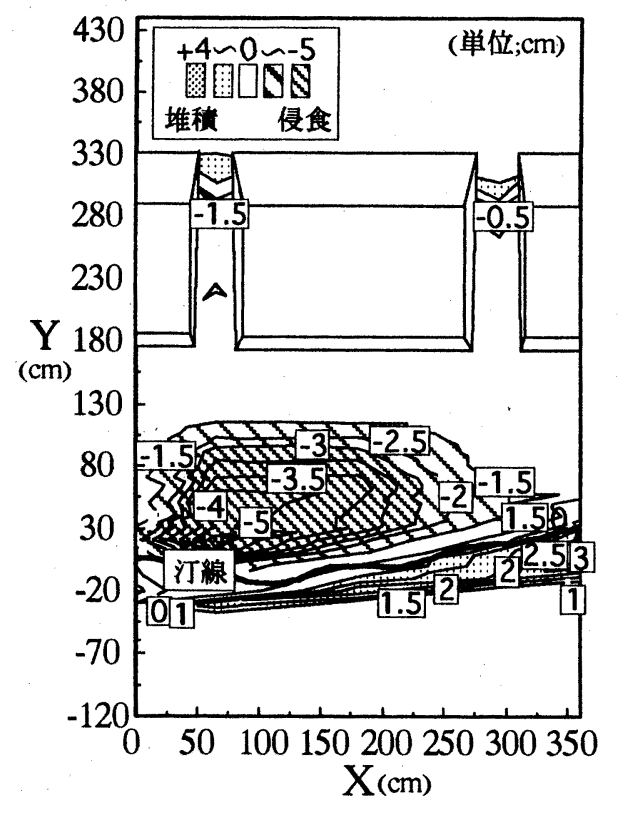

図-9 (a) 人エリーフ周辺の地形変化(ケース 1$)$

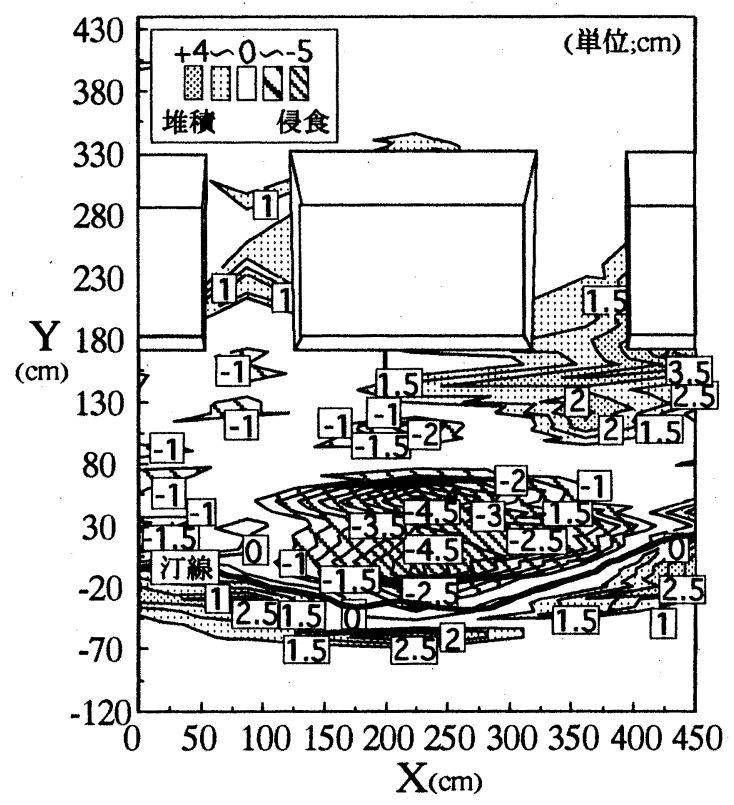

図-9(b) 人エリーフ周辺の地形変化(ケース2)

循環流により運ばれたものと考えられる．また，前 浜上にも砂が堆積していることがわかる. 図-9(c) は, 人エリーフ背後域で向岸流と離岸流が不規則に 起こり, 不安定な循環流が発生していたケース 3 の 地形変化量を示している. 沿岸方向の $\mathrm{X}=0$ から $50 \mathrm{~cm}$ までは砂が堤体背後から汀線まで堆積しているが, X=50から $350 \mathrm{~cm}$ までは砂が侵食されている．この沿 岸方向の不均一な海浜形状には堤体背後での不規則 な流れが関係していると考えられる. 堤体法尻付近 の堆砂は汀線付近の砂が循環流により運ばれたもの で，人エリーフが砂の沖合いの流出を防止してい ることがわかる. 図-9(d) は, 人エリーフ背後域で 1 つの循環流が発生するケース4の地形変化量を示 している. 堤体背後では堆砂が生じ, 堤体法尻と汀 


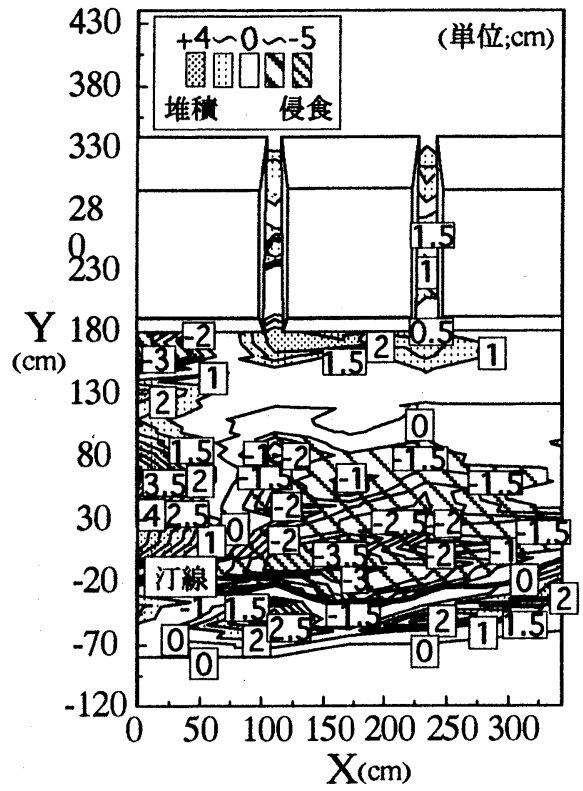

図-9 (c) 人エリーフ周辺の地形変化(ケース 3$)$

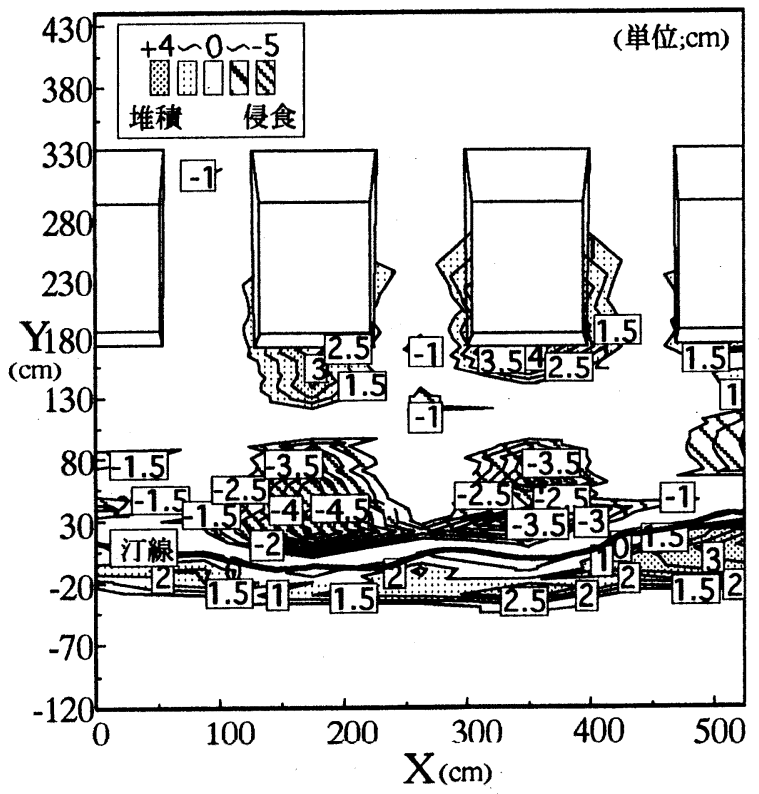

図-9(d) 人エリーフ周辺の地形変化(ケース4)

線の中間地点から汀線付近にかけては侵食されてい る.これは，砂の収支から考えて堤体背後の堆砂は， 人エリーフ堤体が循環流により砂が沖合いに流出す ることを防いだ結果を示している．ステップが発達 し前浜がのび, 人エリーフによる漂砂制御効果が顕 著に現れている.

しかし，図-3に示した流況図は表層での流速べク トルを示している．波の運動に起因する平均流は， 鉛直方向に分布を持ち, 複雑な海底地形の下では上 層と下層とで逆向きの流れが生じる場合も考えられ る. 本研究では下層の流れの測定を行っておらず, 海底砂近傍での平均流を識見することは不可能であ る. しかしながら，砂が移動した平面的な分布を見 ると表層での流れのパターンとの相互関係を確認す ることができる．また数值計算においては波の変形 過程だけではなく, 今後, 3次元解析を行い流れの
鉛直分布を検討する必要があるが，図-5における人 エリーフ背後域での波の平面分布と海底地形の形状 が類似していることが確認できる.

海岸に人エリーフを設置するとき，開口幅が堤長 の7〜8割の長さを越えるときの土砂の移動について は不明であり検討を加えなければならないが，開口 幅を堤長の7から8割の長さに保つと砂の流出を防止 できることがわかった。

\section{5. 結 論}

\section{（1）表層の流れ}

人エリーフ周辺で発生する特有の流れは、堤長と 開口幅の長さの変化に依存し，堤長に対し開口幅が 長くなるほど循環流が発生しやすくなる．また，開 口幅が狭くなり連続堤のようになると弱い岸沖方向 の流れが生じ，堤体背後は䬦んだ状態となった。

\section{（2）波高分布}

リーフ周辺の波高変化は, 堤長と開口幅の長さの 変化に影響されている，堤長に対して開口幅が大き いと，堤体上の波高と開口部での波高の差は大きい ものとなり循環流が発生しやすくなる. 非定常緩勾 配方程式による計算結果と実験值はほぼ一致した。

\section{（3）地形変化}

人エリーフ周辺の地形変化は, 流況パターンに強 く影響されている．循環流が生じず向岸流と離岸流 が発生する場合には, 沿岸方向の漂砂は見られず岸 沖方向の漂砂が生じたが，汀線は前進した。循環流 が発生する場合は，堤体と汀線の中間付近が侵食さ れ、その砂は堤体背後と前浜上に堆積した. また, 砂の分布と表層の流れとの相互関係が確認できた.

\section{参君文献}

1)宇多高明，小俣篤 : 人エリーフの設計法，土木技術資 料, Vol. 29/No. 12, pp. 26-31, 1987.

2)宇多高明，小俣篤：人エリーフ周辺に生じる海浜流と 地形変化，第34回海講論文集，pp. 337-341，1987.

3)渡辺晃, 丸山康樹：屈折・回折・砕波減衰を含屯波浪 場の数値計算法, 第31回海講論文集, pp. 103-107, 1984.

4)丸山康樹，鹿島遼一：砕波減衰を考虑した砕波帯内外 の波浪場の数値計算法の提案とその適用, 電力中央研 究所報告, 研究報告 384041,1985 .

5)渡辺晃, 原哲, 堀川清司：重合した波浪場における砕 波について，第30回海講論文集， pp. 5-9，1983.

6) 合田良実: 砕波指標の整理について, 土木学会論文報 告集, 第180号, pp. 39-49, 1970.

7)磯部雅彦：放物型方程式を用いた不規則波の屈折・回 折・砕波変形の計算法, 第33回海講論文集, pp. 134$138,1986$.

8)谷本勝利, 小舟浩治 : 数値波動解析法による港内波高 分布の計算, 第22回海講論文集, pp. 249-253，1970.

(1997. 9. 30受付) 